\title{
ARCHAEOMETRY
}

\section{AN INVESTIGATION ON THE IMPACT OF PHYSICAL ENVIRONMENT ON THE FORMATION AND CONTINUITY OF ANCIENT SETTLEMENTS, A CASE STUDY \\ THE MEREK RIVER CATCHMENT, CENTRAL ZAGROS, IRAN}

\begin{abstract}
The geographical environment, especially its natural bed, is the area of all actions and reactions resulting from phenomena located on the surface of the earth. The natural environment is the most important factor in the formation of human settlements, especially in different periods. Factors such as altitude, slope, geological structure, faults, water resources, soil, vegetation and land use are natural substrates affecting the distribution of human settlements. The present study aims to investigate the relationship between the formation and continuity of ancient settlements and their environmental bed in the Merek River catchment. To achieve the objectives of the research, 6 natural criteria were considered environmental factors or independent variables, and the area of ancient sites was regarded as a dependent variable. To investigate these factors, Arc Gis and SPSS software programs and inferential statistics quantitative analysis with the Pearson correlation method were used. Additionally, multiple linear Regression was used to investigate the effect of several independent variables on the dependent variable. The results indicate that the areas of the Merek River catchment are directly related to natural factors such as altitude, distance from rivers, and distance from communication routes and type of land use, and a number of other environmental factors are slightly associated with ancient sites. They have caused the people of the past in this region to choose two types of livelihood for their lives.
\end{abstract}

Keywords: Iran, Merek River Catchment, Ancient settlements, Physical.

\section{INTRODUCTION}

rchaeological landscapes from the viewpoint of geomorphology, ecology, and material culture are always changing and the vectors of such changes are taking place in the long-term processes. To recognize the changes of landscapes, it should be studied in its own environmental context. This paper deals with the geodynamics of changing landscapes by
Mohsen Heydari DASTENAEI

Department of Archaeology, University of Tehran Mohsen.heidary4@gmail.com

\section{Kamal Aldin NIKNAMI}

Department of Archaeology, University of Tehran kniknami@ut.ac.ir

DOI: $10.14795 /$ j.v7i4.564

ISSN 2360 - 266X

ISSN-L 2360 - 266X 
socio cultural dynamics of humans under the environmental effects. As Butzer ${ }^{1}$, has pointed out, the primary goal of environmental archaeology should be the characteristics and processes of the biophysical environment that provide a matrix for, and that interact with past human behavior and socio-economic systems of ancient landscapes.

The natural components and the existing cultural phenomena of a landscape have been integrated to form a system in which the presence of all appropriate elements and the occurrence of all processes are at appropriate rates. This integration includes two important points. First, system integrity is reflected in both the natural and cultural elements, and the processes that generate and maintain those elements. Second, integrity is directly associated with the evolutionary context. Therefore, the optimal states of a landscape is up to the integration of its system and it should be noted that any changes within the integrated system, will lead to some changes not only in the physical pattern but even in biological and ecological conditions, thus assessing the degree of change will be depended upon both modified and unmodified systems as well as evaluating existing elements and related processes ${ }^{2}$. Spatial patterns of human settlements are influenced by heterogeneous landscapes and access to natural resources ${ }^{3}$, by which surface water network or river network plays a crucial role in access and mobility. Historically, humans in the early stages of their settlements have followed river networks and flowing surface waters of different regions ${ }^{4}$. They established their settlements close to the rivers network to provide drinking water, agriculture, navigation, water supply and trade 5 . The importance of settlements close to rivers is indirectly reflected in the increasing value of water and the economic and livelihood effects of historic settlements in the vicinity of rivers ${ }^{6}$. In other words, settlement patters indicate type of the living system, along with hidden information about their spatial organization and their change over time ${ }^{7}$.

In this study, the Merek River catchment in the eastern part of the Mahidasht plain, which is also known as the Sar Firuzabad plain and consists of high mountains, steppy rolling hills, forests and rich sedimentary lands. Merek River is one of the rivers of Kermanshah city, which finally enters Seymareh in the west of Mahidasht. This river originates from Sarab Sar Firuzabad located in the southwest of Mahidasht and connects to Qarahsu in the northeast of Mir Azizi village. In fact, this river is considered Mahidasht drainage and has a considerable impact on the livelihood of the region inhabitants of the province. Considering the role of this river in daily life and agricultural reliance on the river water, it can be stated that surface waters in this place play a key role in the economy of agriculture and animal husbandry. The Merek River catchment was surveyed for 60 days in the summer of 2009 under the supervision of

\footnotetext{
BUTZER419,1980.

ANGERMEIER/KARR 1994, 690; see also VOS/MEEKES 1999, 4.

ZHANG et alii $2014,2018$.

${ }^{4}$ CAMPOSA/FORTB/MENDEZ 2006, 88; BERTUZZO et alii 2007, 1.

KUMMU et alii 2011, 1; TURRERO et alii 2013, 4127; CEOLA/LAIO/ MONTANARI 2015, 7064.

6 FANG/JAWITZ 2019, 2.

7 VOGEL 1986, 398.
}

Kamal Addin Niknami. During the study, 332 archaeological sites from different periods from the Middle Paleolithic to the late Islamic period were identified and recorded ${ }^{8}$. Given the abovementioned cases, we aim to study the impact of environmental factors on the Merek River catchment and determine "Which environmental factors play a more fundamental role in the creation, continuation or abandonment of ancient sites? What are the living patterns of the Sar Firuzabad plain based on the distribution of settlements in the region? How many living patterns can be found in this area?"

\section{MEREK RIVER CATCHMENT}

In general, the Zagros area consists of two parts: high and parallel mountains and alluvial and sedimentary mountain plains ${ }^{9}$. Since ancient times, alluvial zones, including plains and alluvial fans, especially in areas with hot and dry climates, due to favorable environmental conditions, are attractive areas for population in the location of settlements. These areas have long been the site of civilization and human life in the Quaternary period until today ${ }^{10}$. The Merek River catchment is one of these alluvial zones with high mountains, alluvial fields with large and small alluvial fans, scattered rolling hills, forest cover at the edge of the plain and agricultural lands, which is located 35 $\mathrm{km}$ southeast of Kermanshah province (Fig. 1). In fact, this part of the Merek River catchment is located in the Central Zagros Mountains ${ }^{11}$ and along the natural plain of Mahidasht; in terms of natural geography, it stretches to the southern and southeastern part of Mahidasht ${ }^{12}$. As we know, this area includes mountainous parts with forest areas, plains, rolling hills, along with pastures and agricultural lands ${ }^{13}$. Merek River is located in the middle of the Sar Firuzabad plain and originates from the southwestern and southeastern heights of the Mahidasht plain and the green heights of Amo-Nesar and Kuh-e Sefid. In fact, this river is regarded as Mahidasht water drainage, and its route in the source from east to west and after passing through the middle of Mahidasht near a place called Doab is connected to the Qarahsu River. This region is located in one of the open plains of the country, which starts with a gentle slope from the mountains and ends at central lower point or points; it also ends in a main drain, which is enclosed as a composite syncline between the mountains. Additionally, the central part of the synclinal plain has considerable alluvial sediments and most of the areas of the Sar Firuzabad plain are located on alluvial fans and alluviums of the fourth geological period. Usually, the presence of fine-grained sediments provides good materials for agriculture, pottery and other economic activities and suitable conditions for establishments ${ }^{14}$.

In addition to the Merek River and its seasonal tributaries, throughout the Sar Firuzabad plain, there

NIKNAMI/NIKZAD 2012，455; NIKNAMI/ASKARPOUR 2013，346; NIKNAMI/IRANDOUST/TAHMASEBI 2013, 71; HEIDARI 2016, 30; NIKNAMI/MIRGHADERI 2019, 156.

9 HEIDARI/GHASIDIAN/CONARD 2007, 80.

10 MAGHSOUDI 2008, 74

BROOKES 1989, 4.

2 NIKNAMI/ASKARPOUR 2015, 312.

13 HESHMATI et alii 2011, 1037.

${ }^{14}$ MAGHSOUDI et alii 2012, 7. 


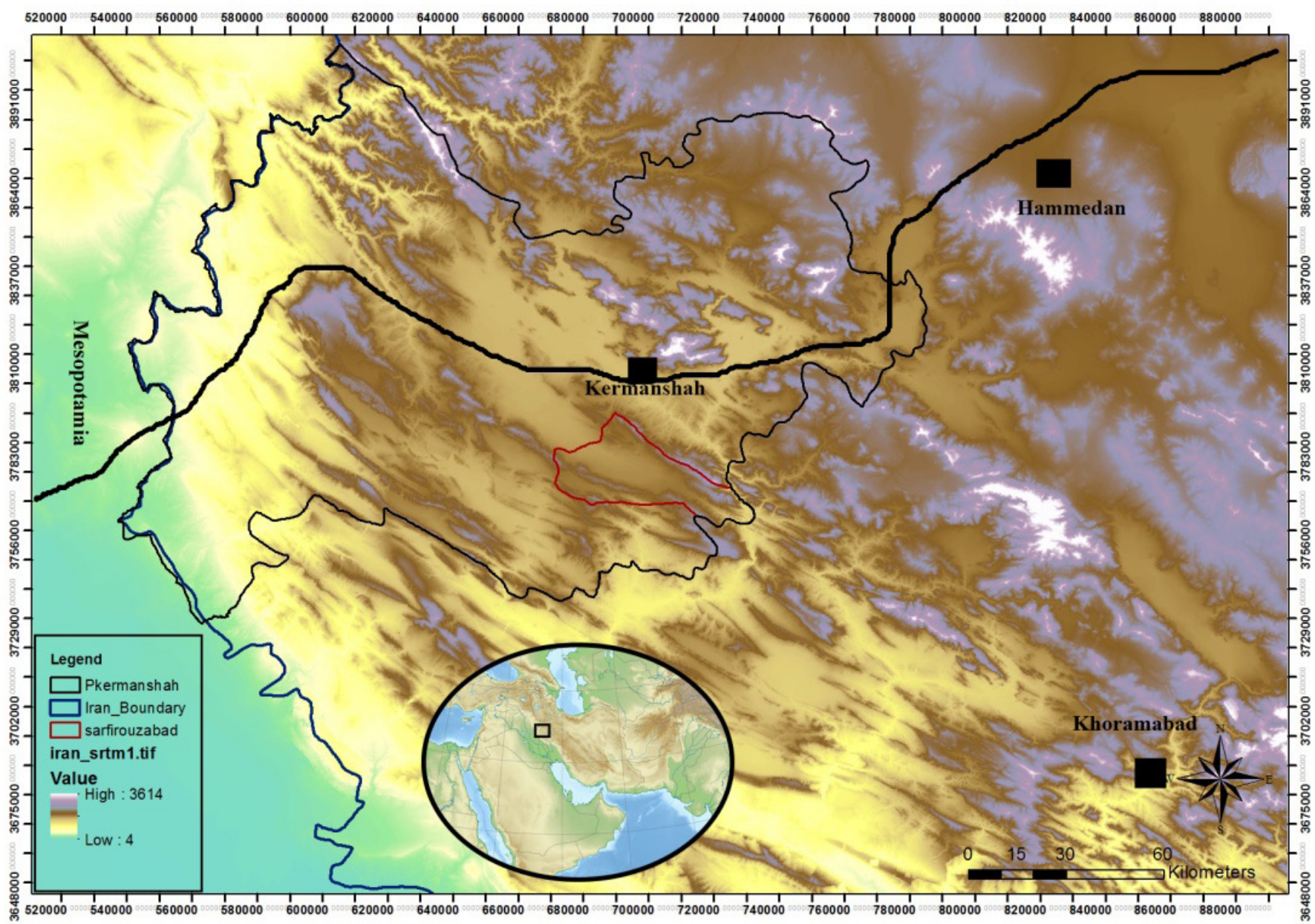

Fig 1. Location of the Sar Firuzabad plain on the Great Khorasan Road

are several springs, most of which have dried up during archaeological excavations and have already been recorded ${ }^{15}$. Two mountain ranges southwest and northeast surround this plain. The northeastern strip includes the mountains of Kamajar (Kame Jar), Zangalian, Khora Tau and Kuh-e Sefid. The mountains of the southwestern strip are lower and more connected. The mountains of this section include Nesar, Kalemal, Lalabad (Laleh Van), Si Volks, Shirnarmi, Barikeh and Qala Ghazi (Qalaqazi) ${ }^{16}$.

In fact, this plain, along with a part of the Mahidasht plain, is also called the Merek River catchment ${ }^{17}$, which geologically includes mountains, foothills and rolling hills, and has a semi-arid cold climate with relatively cold winters and moderate summers. The average annual rainfall of this plain is 400 to $500 \mathrm{~mm}$. From the study of statistics and meteorological information, such conclusions can be drawn that the annual temperature is from $5.5^{\circ} \mathrm{C}$ in January to $26.7^{\circ} \mathrm{C}$ in July. The temperature in April is $12.1^{\circ} \mathrm{C}$ and until October, the temperature is more than the annual average. In other words, 6 months of the year, the temperature is above $13.7^{\circ} \mathrm{C}$ and from November to April, the negative situation is seen at temperatures ${ }^{18}$.

Geologically, a major part of the Merek catchment

\footnotetext{
${ }^{15}$ BROOKES 1989, Pl. II.

${ }_{16}$ NIKNAMI/MIRGHADERI 2019, 164.

${ }_{17}$ NIKNAMI et alii 2016, 84.

${ }^{18}$ MOHAJER MILANI et alii 2010, 7.
}

is occupied by the Zagros folded belt, which is a sequence of Precambrian-Pliocene shelf sediments. These sediments have been folded into a series of huge anticline mountains and syncline valleys that pass through a narrow zone of thrusting. Drainage pattern and topography dips have been formed by local folded rocks and faults. Marl, limestone, sandstone and shale are the important materials/sediments forming the geological formations ${ }^{19}$.

Despite being located in the Central Zagros, adjacent to Mahidasht and being located on the side of the Great Khorasan Road, this region has not received much attention of archaeologists. Archaeologists who have visited Sar Firuzabad include Schmidt ${ }^{20}$ in the 1930s, Stein in western Iran during the 1940s in Mahidasht ${ }^{21}$, and Braidwood in 1959-60 in this region (Mahidasht) and neighboring areas ${ }^{22}$. In 1963-1967 while Goff was conducting archaeological research in the Pishkuh area of Lorestan, he visited the Sar Firuzabad plain and identified and recorded some sites in the area $^{23}$.

In 1968, Ali Akbar Sarfaraz, Mohammad Rahim Sarraf and Ismail Yaghmaei recorded 43 significant mounds

\footnotetext{
${ }^{19}$ HESHMATI et alii 2011, 22.

${ }^{20}$ SCHMIDT 1940, 85

${ }^{21}$ STEIN 1940, 414.

22 BRIDWOOD 1961, 3; BRAIDWOOD/HOW/REED 1961, 2008; LEVINE 1974, 487.

${ }^{23}$ SEE GOFF 1971, 140, Fig 4.
} 
Table 1. The correlation between the ancient sites of the Merek River catchment and environmental factors

Correlations

\begin{tabular}{cc|ccccccc}
\hline & & Extention & Periods & Elevation & Rivre & Road & Slope & Landuse \\
\hline \multirow{2}{*}{ Extention } & Pearson Correlation & 1 & $.792^{* \prime}$ & $.108^{*}$ & $.225^{* *}$ & $.115^{*}$ & .067 & $-.180^{* *}$ \\
& Sig. (2-tailed) & & .000 & .050 & .000 & .037 & .223 & .001 \\
& $\mathrm{~N}$ & 332 & 332 & 332 & 332 & 332 & 332 & 332 \\
\hline
\end{tabular}

** Correlation is significant at the 0.01 level (2-tailed).

${ }^{*}$ Correlation is significant at the 0.05 level (2-tailed).

in Mahidasht. The Ontario Museum Archaeological Project, led by Lewis Levine, examines parts of Sar Firuzabad in a limited way $^{24}$. McDonald mentions three settlements from the Neolithic period and a number of Chalcolithic settlements with $\mathrm{J}$ ware in Sar Firuzabad ${ }^{25}$. Members of the Royal Ontario Royal Museum's Mahidasht Project Board discussed the geological status of the area, especially the Mahidasht area, and the impact of these processes on the formation, continuation, and burial of ancient sites in the $\operatorname{area}^{26}$.

To assess the interactions between humans and their surrounding environment a fieldwork was conducted by University of Tehran in 2009 in the Sar Firuzabad plain aiming mainly at understanding how the human settlements were evolved in the divers environmental conditions? At Due to this situation, in 2009, a delegation from the University of Tehran headed by Kamal Addin Niknami, to study and identify the sites of the Sar Firuzabad Rural District with the history of human communities and to understanding investigate settlement patterns in prehistoric and historical periods, entered Sar Firuzabad. They were surveyed for 60 days in the summer of 2009. During the 2009 survey, 332 Sites from different periods from the Middle Paleolithic to the late Islamic period were identified and recorded. Discovered remains include caves, grounds, hills, Imamzadeh, castle, landmarks.

\section{RELATIONSHIP BETWEEN ENVIRONMENTAL FACTORS AND THE ANCIENT SITES OF SAR FIRUZABAD}

According to the discussions and study of prehistoric sites in the region, especially the Sar Firuzabad plain, it can be concluded that in the growth and development of ancient sites in the Sar Firuzabad plain, primarily natural factors and secondarily cultural factors have been effective ${ }^{27}$. In other words, environmental factors have a significant impact on the distribution patterns of ancient sites. Arable land, adequate rainfall, adequate fuel resources, access to water resources as well as access to communication routes are among these geographical and environmental conditions ${ }^{28}$. Therefore, understanding the environmental factors affecting the formation of human settlements is highly important. One of the most important goals of field studies in archeology

\footnotetext{
${ }^{24}$ LEVINE 1974, 489, Fig 1.

${ }^{25}$ LEVINE 1974, 488; MC DONALD 1979, 566.

${ }^{26}$ BROOKES/LEVINE/ROBIN 1982; BROOKES 1989.

${ }^{27}$ NIKNAMI/ASKARPOUR 2013, 534.

${ }^{28}$ HOLE 1987, 22.
}

is to study how human societies interact with each other and the ecology in which they live. For this reason, in spatial analysis, the relationship between ancient sites and their environment such as altitude, distance to the nearest water sources and roads, slope, vegetation, slope direction and other factors is considered ${ }^{29}$.

To achieve the desired goal in this type of analysis, it is necessary to determine a specific criterion to measure the potential impact of these factors in the formation of these deployments. For this purpose, in the first stage, by collecting specific and measurable data related to areas and natural resources, the GIS software has been used to analyze, compare the results and understand the problem, as well as integrate information layers with field findings. During this process, first basic maps were prepared, and then the location of settlements was analyzed in relation to each layer. In the next step, using the SPSS software as well as using statistical analysis and correlation coefficient calculation, the percentage of impact of the above factors was determined (Table. 1). In this regard, environmental factors such as altitude, distance of sites from rivers, distance of sites from main routes, slope of the site, type of land use were considered independent variables, and the area of ancient sites was regarded as a dependent variable. In the correlation coefficient, the relationship between the variables is considered between +1 and -1 . The closer the relationship between the variables is to +1 , the greater the correlation, and the closer to zero, the lower correlation, and if negative, the result is inversed ${ }^{30}$. Then, using correlation analysis, the relationship between each of the environmental

\section{Sites}

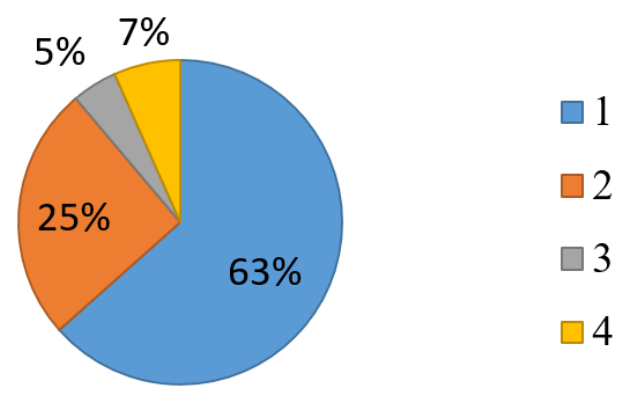

Fig. 2. The number of the sites in terms of periods

CLARKE 1977, 119

30 SPRENT/SMEETON 2016, 321. 


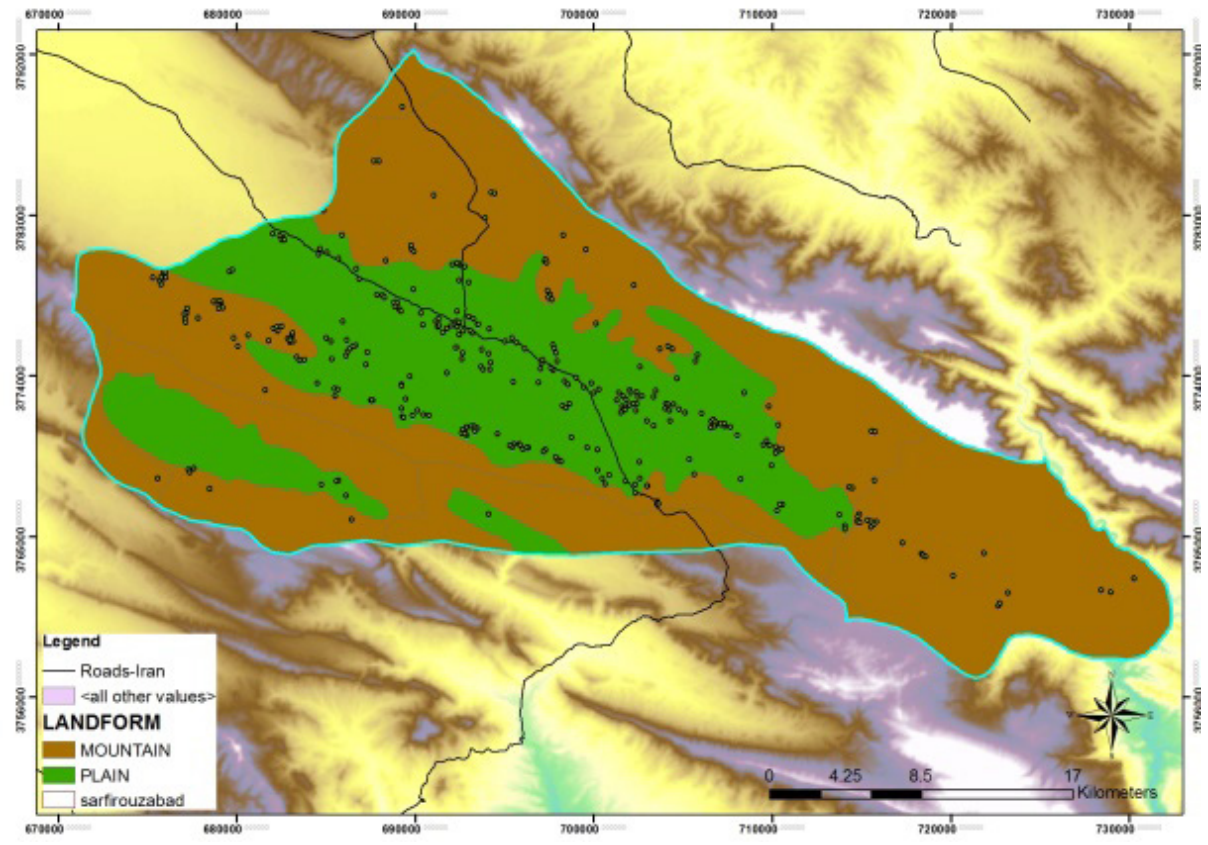

Fig. 3. Location of the sites in the plains and mountainous area

factors and the ancient sites is measured, and then the environmental factors that have played a role in the, creation and continuation of the ancient sites are described and analyzed.

\section{NUMBER OF PERIODS OF ANCIENT SITES}

Usually, the number of periods in each ancient site is higher and its height is higher, demonstrating the importance of the geographical location in which the ancient site is located as considered by its inhabitants in different periods. With this assumption, the number of periods in the Sar Firuzabad plain was examined. As mentioned, 332 sites were identified in the Merek River catchment, of which 210 sites or $63 \%$ are single-period ones, $84 \%$ of sites or $25 \%$ are two-period ones, 15 sites or $5 \%$ are three-period ones, and 22 sites or $7 \%$ are four-period ones (Fig. 2). Pearson correlation coefficient shows the correlation between the site of Sarfirouzabad area and the factor of the number of periods (+/792) (Table. 1); this chart indicates a direct, high and positive correlation between the area of the sites and the number of periods; in other words, large sites with multiple layers are larger than other sites, and as the period number of the sites decreases, the area of the sites decreases.

\section{ELEVATION OF ANCIENT SITES FROM SEA LEVEL}

One of the important issues in the study of ancient sites is the distribution of sites at different altitudes. This factor can affect the way and type of people's livelihood. The population of rural areas and the load of infrastructure are also directly associated with the altitude factor. In fact, the main reason for the decrease in the number of inhabitants in rural settlements located in mountainous areas is the altitude factor. As altitude increases, the share of agricultural land decreases, the climate cools, and space for agricultural activities is limited. Therefore, villages will be small in scale ${ }^{31}$.

\footnotetext{
${ }_{31}$ POTOSYAN 2017, 2.
}

Altitude in this region varies between 1047 and 2774 meters and mainly consists of two distinct units, which are mountainous areas and plateau plains. Its high and mountainous regions are divided into three parts:

- The first part includes altitudes of higher than 2000 meters, which are characterized by steppe slopes, severe erosion and narrow valleys.

- The second part is areas with an altitude of 1500 to 2000 meters, which is located between the steppe folds of mountains and flat plains, and includes steppe rolling hills and forest areas.

- The third part is flat and sedimentary areas that have a height of 1000 to 1500 meters and are considered important centers of population and agriculture in the region. In general, the areas of this area can be seen in two parts. Out of 332 sites, 142 sites or $43 \%$ are located in rolling and steppe hills and 189 sites or $57 \%$ are located in the plain floor (Fig. 3, 4). In general, it can be stated that 2 sites or 0.5 are at an altitude of $900-1200$ meters, 105 sites or $32 \%$ at an altitude of $1200-1500$ meters, 222 sites or $67 \%$ at an altitude of $1500-1800$ meters and 3 sites or $1 \%$ at an altitude of 1800-2100 meters (Fig. 5, 6). Investigation of the Pearson correlation coefficient on the area of the sites with the altitude factor from sea level shows 0.108 (Table. 1) that this figure expresses a direct, high and inverse correlation. In other words, the higher the altitude, the smaller the area of the ancient sites is; it means that smaller areas are seen at higher altitudes.

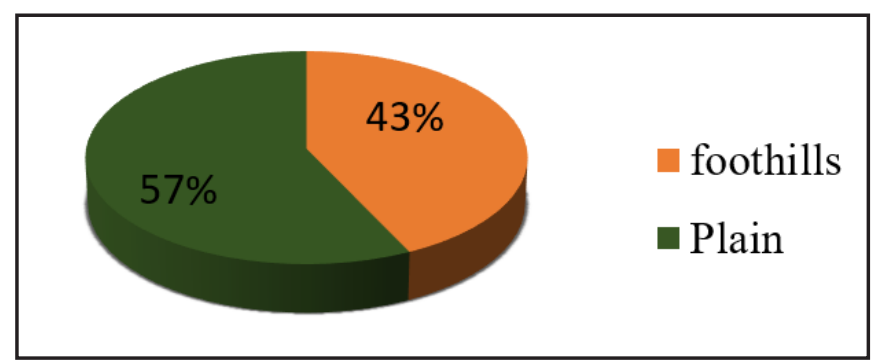

Fig. 4. Number of sites in plains and rolling hill and mountainous areas

Altitude is a limiting factor in the spatial establishment of settlements, so that at altitudes above 2000 meters, the number of settlements is reduced, and only nomadic areas are exempt from this rule. Elevation slopes are usually not a good place to establish settlements, even though they are close to water sources, since their natural and environmental conditions are not suitable for sedentism and today's villages are less developed in this area. This is why temporary shelters are seen in this area, and because they are inhabited only during several months of the year. 


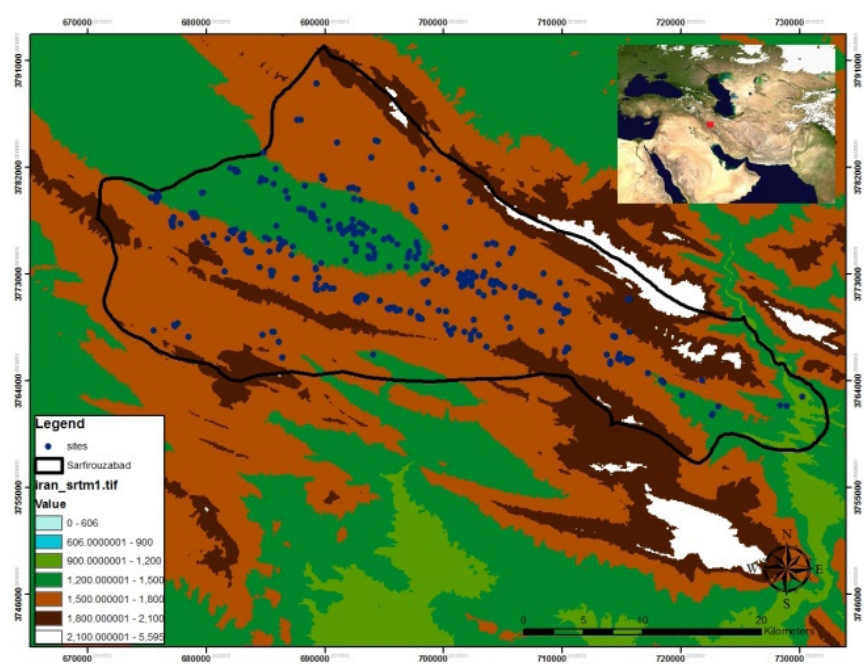

Fig. 5. Position of ancient sites relative to altitude from sea level

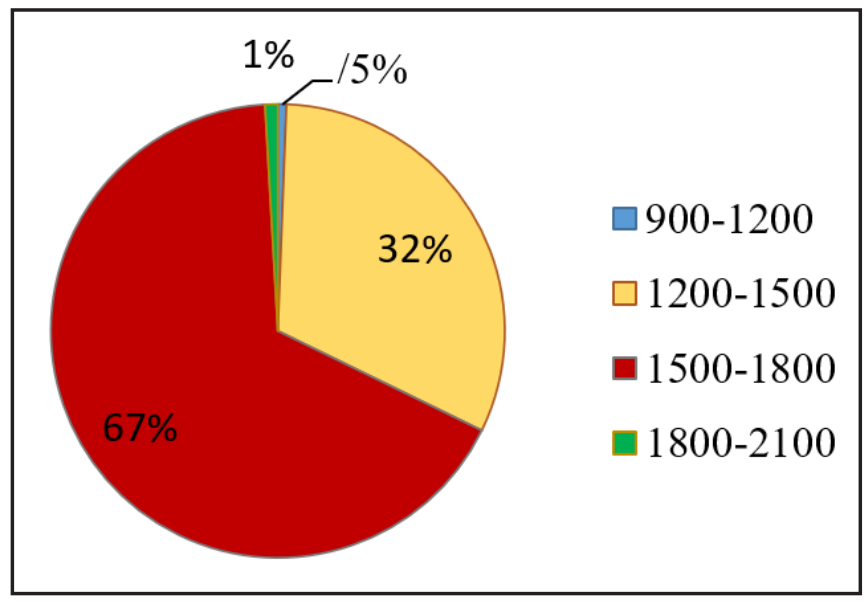

Fig. 6. Number of sites in percentage relative to altitude from sea level

\section{DISTANCE OF ANCIENT SITES FROM RIVERS}

Today, as in the past, water resources play an essential role in both the organization and settlement of lands and in the economic and social structure of groups ${ }^{32}$. In other words, distribution of the water network clearly determines the location, pattern and shape of the settlements. Water is vital for agriculture, and in most cases, the agricultural boom grows with access to fresh water. Hence, the economic value of water is particularly high. In agricultural areas with hot and dry or seasonal climates, the availability of water is extremely valuable ${ }^{33}$. Accordingly, 147 archeological sites in the area of Merek or $44 \%$ at a distance of $0-500$ meters, 67 sites or $20 \%$ at a distance of $500-1000$ meters, 34 sites or $10 \%$ at a distance of $1000-1500$ meters, 12 sites or $4 \%$ at a distance of 1500-2000 meters, 9 sites or $3 \%$ at a distance of 2000-2500 meters, and 63 sites or $13 \%$ are located at a distance of more than 2500 meters from the main water sources (Fig. 7 and 8). The Pearson correlation coefficient is 0.225 , indicating a direct and high correlation; in other words, the sites along and near the main river are larger than the sites farther away from the river.

32 MAGANZANI 2018, 88.

${ }^{33}$ MAMASSIS/KOUTSOYIANNIS 2018, 31

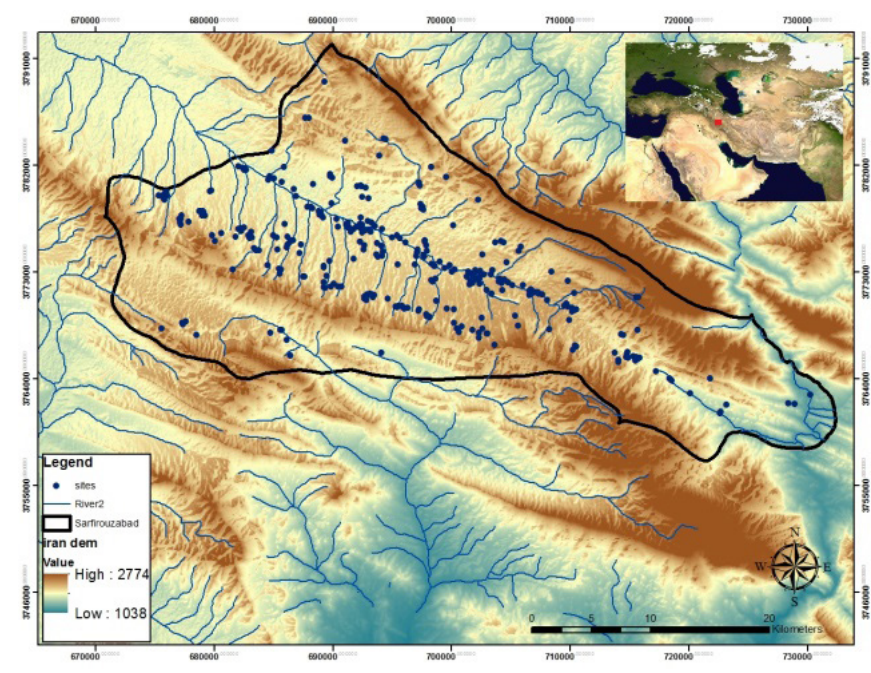

Fig. 7. Position of the ancient sites relative to water sources

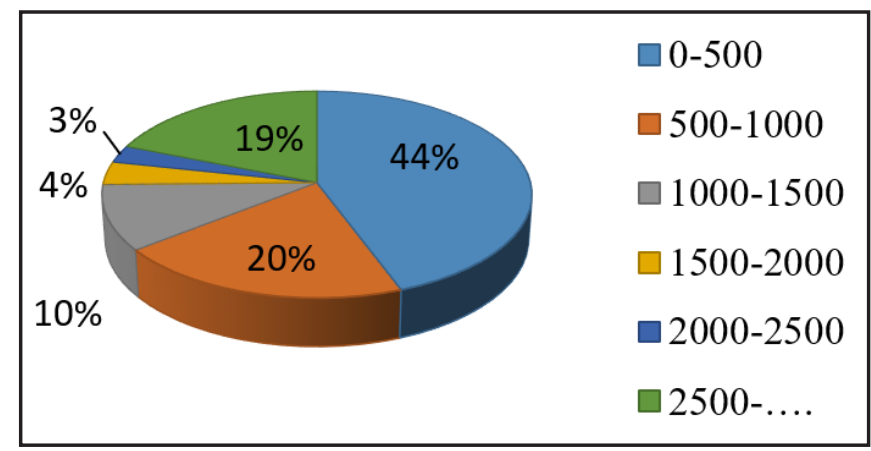

Fig. 8. Number of the sites in relation to water resources

\section{DISTANCE OF ANCIENT SITES FROM COMMUNICATION ROUTES}

The study of roads and the exploitation of natural passages are highly important in archaeological research; roads have been a factor in the development and progress of groups and nations, and cultural, social, and economic exchanges between nations, tribes, and civilizations have historically occurred through roads and transportation routes. The most important road in the Central Zagros is the Great Khorasan Road, which crosses the Mahidasht plain ${ }^{34}$ and connects the central plateau of Iran to Mesopotamia ${ }^{35}$. Although this road does not pass through this area, it passes through the northwest side of this area. In fact, the Sar Firuzabad plain is located along present-day communication routes, which have been used since ancient times in this region ${ }^{36}$ and a large number of sites are located next to this modern route, demonstrating the use of this path by people in the past. In this regard, it can be stated that 62 sites or $19 \%$ of sites at a distance of $0-500$ meters, 24 sites or $7 \%$ at a distance of $500-1000$ meters, 23 sites or $7 \%$ at a distance of 1000-1500 meters, 13 sites or $4 \%$ at a distance of 1500 2000 meters, 6 sites or $2 \%$ at a distance of 2000-2500 meters and 204 or $64 \%$ are at a distance more than 2500 meters (Fig. 9 and 10). The Pearson correlation coefficient is 0.115 (Table. 1) indicating a positive, direct and high correlation and showing that the sites next to the main communication

\footnotetext{
4 LEVINE 1974, 487.

5 HENRICKSON 1985, 4; HENRICKSON 1989, 371; ABDI 1999, 33.

${ }^{36}$ NIKNAMI/MIRGHADERI 2019, 167.
} 


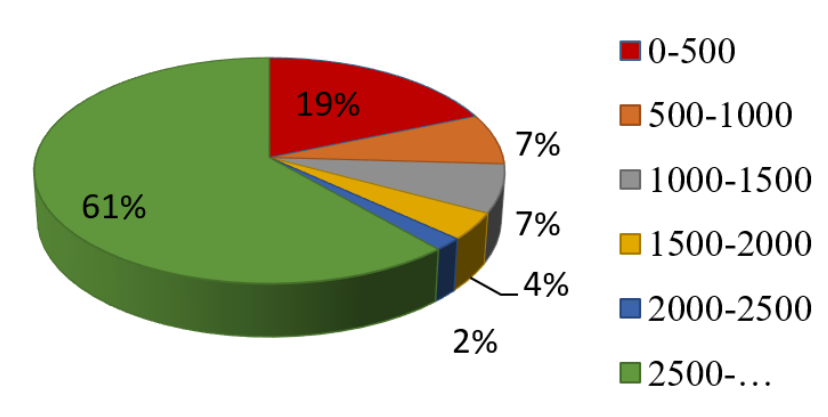

Fig. 9. Archaeological sites and their percentage relative to the main routes

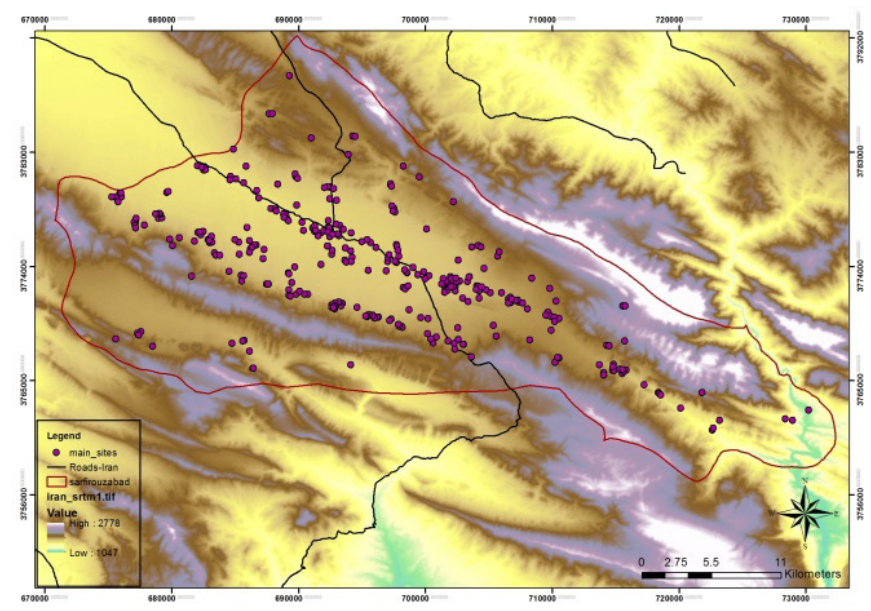

Fig. 10. Position of the ancient sites relative to the main communication routes

route are larger than the ones farther away.

\section{THE SLOPE OF THE LOCATION OF ANCIENT SITES}

Slope is effective in establishing settlements in terms of the location of the village directly and the creation of suitable conditions for livelihood (agricultural products). In principle, it is possible to carry out agricultural activities, especially agricultural activities at low slope levels. The maximum slope for agricultural activities is 15 degrees. According to the standard, smooth and low slopes are suitable for settlements, and the maximum land slope for settlement should not exceed 11 degrees. In other words, the best slope for human settlement is slopes lower than 11 degrees ${ }^{37}$; however, it varies slightly depending on environmental conditions ${ }^{38}$. In the study area, 262 sites or $72 \%$ on the slope of $0-5$ degrees, 65 sites or $19 \%$ on the slope of 6 -11 degrees, 3 sites or $1 \%$ on the slope of $12-18$ degrees and 2 sites on the slope of 18-23 degrees (Fig. 11 and 12). The Pearson correlation coefficient between the area of Sar Firouzabad sites and the slope factor shows the location of +0.067 (Table. 1). This figure is close to zero and means that there is no correlation between the area of the sites and the slope of their location. Perhaps one of the reasons for this is that either some of the mentioned sites are seasonal, and the degree of slope on which they are located was not

\footnotetext{
37 ANABESTANI 2011, 96: Table 6.

38 ZOMORODIAN 2004, 29.
}

important to their residents, or a number of large sites are located on a high slope and some small and seasonal sites are also located on a low slope or 0-5 degrees. This phenomenon is also seen in the region today, the nomads and pastoralists of the region, set up their tents wherever they see fit. For this reason, most of their tents can be seen on the slopes of rolling hills, inside gorges, mountain slopes, or between hills and ramps. Perhaps, another reason for this is that since the settlement time of the people is not permanent, and the period of their settlement is short, the place they choose to settle, should be a place far from wild animals and safe from natural factors such as strong winds ${ }^{39}$; this causes them to choose the slopes of the mountains, between rolling hills, the slopes of rolling hills and the sloping neighborhoods. In addition, slopes lower than $15 \%$ are the most suitable slope for agricultural activities, which, if other environmental and non-environmental conditions are favorable, will lead to an improvement in the quantity and quality of agricultural products. In general, it should be stated that lands with high slopes are not usable for agriculture, and higher slopes include meadows, pastures, forests, fodder and mountain pastures; therefore, the choice of different slopes indicates a short-term settlement.

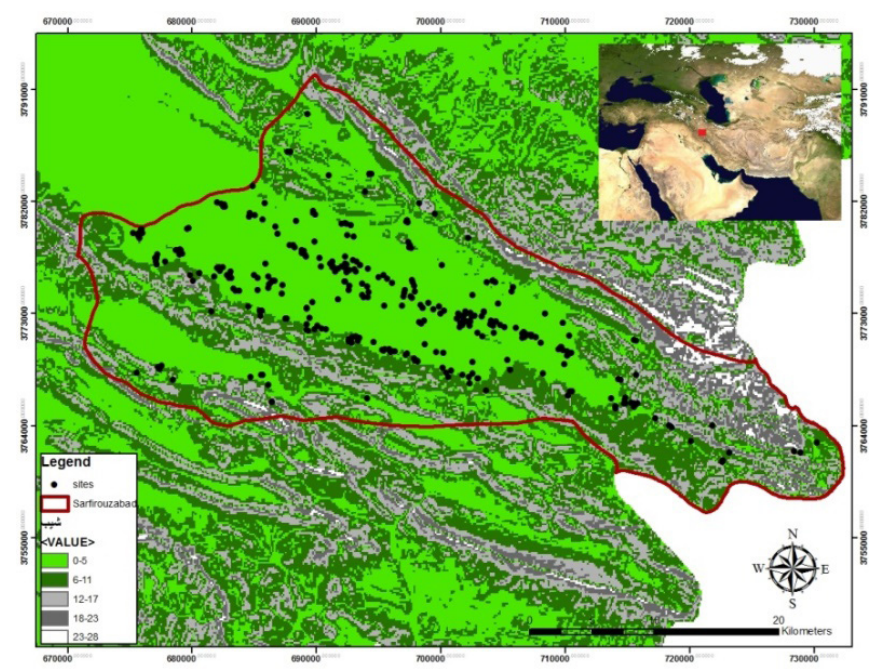

Fig. 11. Position of the sites relative to the degree of slope

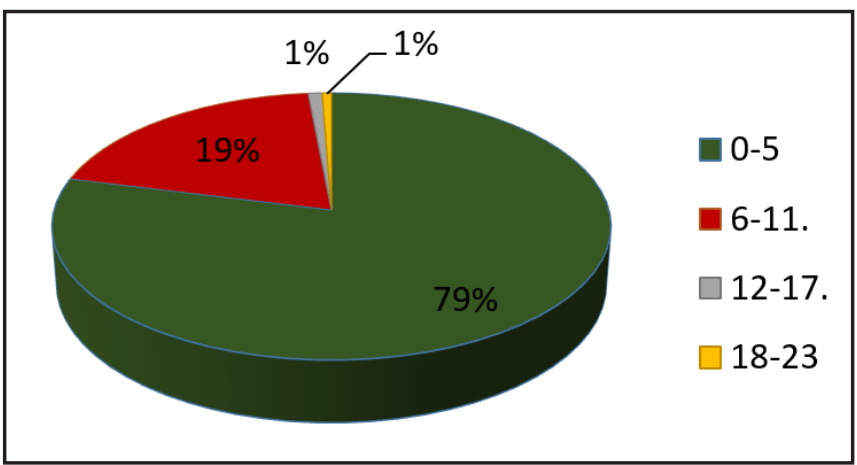

Fig. 12. Ancient sites and their percentage relative to the degree of slope

\section{TYPE OF LAND USE AROUND ANCIENT SITES}

Changes in rural settlements are a reflection of the relationship between humans and the earth. This relationship

\footnotetext{
${ }^{39}$ HOLE 2004, 114.
} 


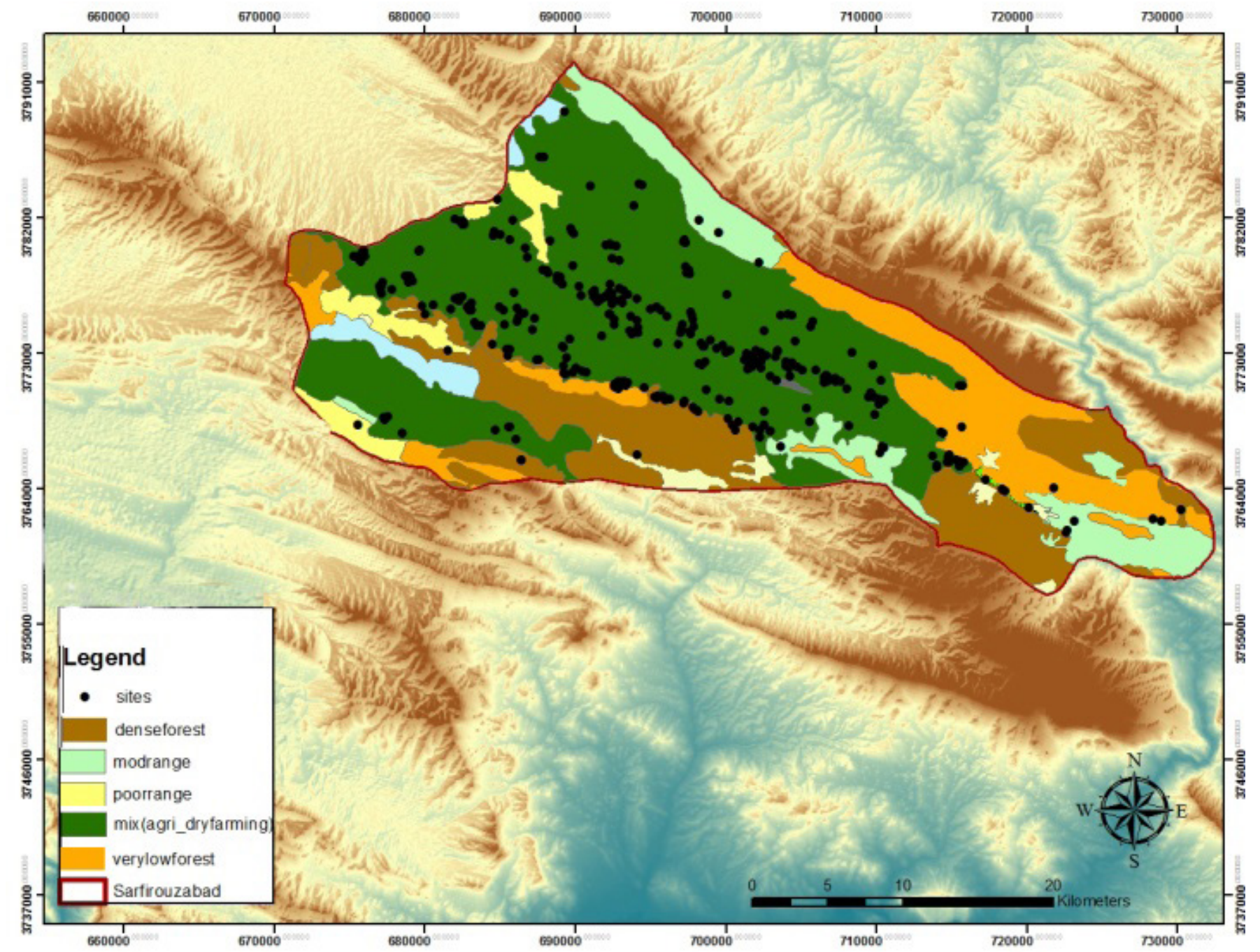

Fig. 13. Position of the sites relative to vegetation

can include changes in the natural environment, continuous population growth, social changes and other changes. These factors cause the use of land in these areas to take various forms $s^{40}$. The distribution of settlements is directed related to the type of land use and vegetation of the region. Thus, in the areas where lands are allocated to irrigated agriculture, the number of settlements is practically very large and dense, and conversely, in areas where wider pastures, settlements are smaller and less populated, and their density is very low. Since irrigated agricultural lands follow rivers, the distribution of settlements is more affected by this factor. This is also true in Sar Firuzabad and 287 sites or $88 \%$ of the sites are located in irrigated and rain fed agricultural lands. Furthermore, 13 sites or $4 \%$ are in dense forest cover, 10 sites or $3 \%$ are in medium cover rangelands, 2 sites or $1 \%$ are in poor rangelands, and 12 sites or $4 \%$ are in lands with very low forest cover. In summary, $8 \%$ of the land is located in the forest or forest edge, $4 \%$ in pastures and $88 \%$ in rainfed and irrigated lands (Fig 13 and 14). The Pearson correlation coefficient shows the degree of correlation between the area of Sarfirouz Abad sites and the land use factor as -0.180 (Table. 1). This figure indicates a high and significant inverse relationship between land use and area of the sites; in other words, we should expect large-area sites be formed on areas

\footnotetext{
$\overline{{ }^{40} \mathrm{CAO} \text { et alii } 2018,332 .}$
}

with more vegetation or land that is prone to agriculture, and vice versa, in the highlands with less vegetation, such as rolling hill areas, seasonal and small sites are formed. However, this is not the case and small sites are also seen in areas prone to agriculture; that is why this number has been reversed.

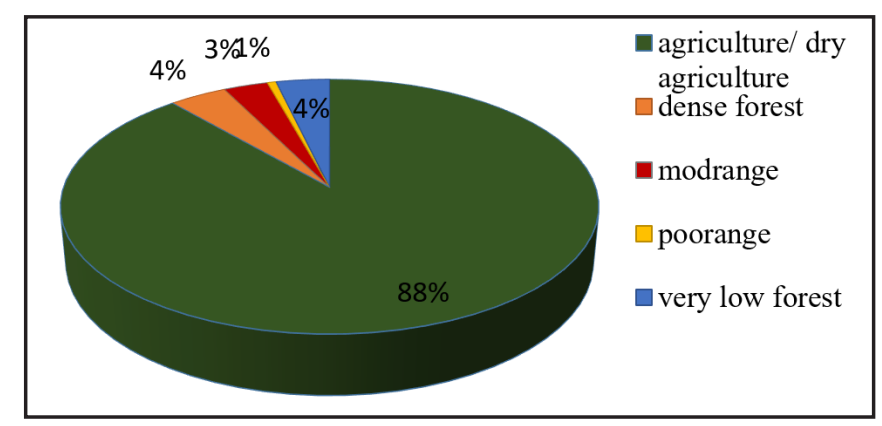

Fig. 14. Archaeological sites and their percentage in relation to land use

\section{ANALYSIS OF THE IMPACT OF ENVIRONMENTAL FACTORS ON ANCIENT SITES}

Multiple linear Regression is usually used to examine the effect of several independent variables on the dependent variable. In this method, researchers seek to discover the relationship between independent variables and 
dependent variables and want to predict the rate of change of the dependent variable based on the rate of change of the independent variable ${ }^{41}$. In this section, the multiple linear Regression method, along with the simultaneous method has been used. The following tables are the output of this analysis.

In the table 2 , the value of $\mathrm{R}$ is known as the multiple correlation coefficient and shows the amount of multiple correlation between the set of independent and dependent variables and is equal to 0.906 . This number expresses the intensity of the correlation between the set of environmental factors and the area of the sites, which is relatively intensive and is highly correlated. In addition, $\mathrm{R}^{2}$ is also known as the coefficient of determination and shows the extent to which the variance and variance of the dependent variable are explained by a set of independent variables. In other words, it shows how much of the dependent variable can be explained by the independent variable. In this analysis, the number 0.850 also indicates that the variable of environmental factors can explain 85 of the changes of the dependent variable or the area of the ancient sites of the Merek catchment.

Table. 2. Summary of the output model of the linear multiple Regression

Model Summary

\begin{tabular}{ccccc}
\hline Model & $\mathrm{R}$ & R Square & $\begin{array}{c}\text { Adjusted R } \\
\text { Square }\end{array}$ & $\begin{array}{c}\text { Std. Error of the } \\
\text { Estimate }\end{array}$ \\
\hline 1 & $.906^{\mathrm{a}}$ & .850 & .843 & 6588.314 \\
\hline
\end{tabular}

a. Predictors: (Constant), Landuse, Elevation, Road, Periods, Slope, Rivre

b. Dependent Variable: Extention

Table 3 shows the analysis of Regression variance and states whether the Regression model can significantly predict changes in the dependent variable. The Sig column shows the statistical significance of the Regression model and if less than 0.05., it indicates that the model used is a good predictor and shows the significance of the Regression model. In this table, the F value of the Regression model is zero and therefore the Regression model with six variables is significant.

Table. 3. Analysis of Regression variance

\begin{tabular}{|c|c|c|c|c|c|c|}
\hline \multicolumn{7}{|c|}{ ANOVA $^{a}$} \\
\hline \multicolumn{2}{|c|}{ Model } & Sum of & df & Mean Square & $\mathrm{F}$ & Sig. \\
\hline \multirow[t]{3}{*}{1} & Regression & 2.615 & 6 & 43579669599 & 100.400 & $.000^{\mathrm{b}}$ \\
\hline & Residual & 1.411 & 325 & 434058819 & & \\
\hline & Total & 4.025 & 331 & & & \\
\hline
\end{tabular}

a. Dependent Variable: Extention

b. Predictors: (Constant), Landuse, Elevation, Road, Periods, Slope, Rivre

Table 4 is a table of different Regression coefficients providing us with information about the predictor variables and indicate that the period variables, distance from rivers, altitude, communication paths, and land use are

\footnotetext{
${ }^{41}$ YAN /GANG SU 2009, 41.
}

significant (sig column). The Beta Regression coefficient indicates the relative share of each independent variable in predicting the dependent variable, or in other words, we can determine which variables had the greatest impact on the dependent variable. Any factor with a larger beta is more important in the Regression model. In interpreting these findings, it is suggested that by increasing one value of the standard deviation in the distance from the rivers, the standard deviation of the area of the sites increases by 0.88 . Moreover, by increasing one value of the standard deviation in the distance from the communication paths, the standard deviation of the area of the sites increases by 0.66 . If the standard deviation is higher in altitude from sea level, the standard deviation of their area reduces by 0.67 .

Table. 4. Different Regression coefficients

\section{Coefficients $^{\mathrm{a}}$}

\begin{tabular}{|c|c|c|c|c|c|c|}
\hline & & \multicolumn{2}{|c|}{$\begin{array}{c}\text { Unstandardized } \\
\text { Coefficients }\end{array}$} & \multirow{2}{*}{$\begin{array}{c}\begin{array}{c}\text { Standardized } \\
\text { Coefficients }\end{array} \\
\text { Beta } \\
\end{array}$} & \multirow[b]{2}{*}{$\mathrm{t}$} & \multirow[b]{2}{*}{ Sig. } \\
\hline \multicolumn{2}{|c|}{ Model } & B & Std. Error & & & \\
\hline \multirow[t]{7}{*}{1} & (Constant) & -15597.012 & 8053.484 & & -1.937 & .054 \\
\hline & Periods & 15261.938 & 652.257 & .778 & 23.399 & .000 \\
\hline & Rivre & 15561.160 & 778.397 & .885 & 25.403 & .000 \\
\hline & Road & 135397.209 & 543.104 & -.668 & -21.004 & .046 \\
\hline & Elevation & 135797.390 & 501.088 & -.677 & 23.059 & .090 \\
\hline & Slope & 1835.881 & 937.277 & .067 & 1.959 & .051 \\
\hline & Landuse & -1692.487 & 543.958 & -.506 & -20.111 & .092 \\
\hline
\end{tabular}

Dependent Variable: Extention

Table 5 examines the distribution of residuals according to the Regression conditions. In this table, residuals should have a normal distribution with a mean of zero and a variance of 1 . In the second and last row, which is related to the residuals, the mean is zero and the standard deviation or variance is 1 . This will be another reason for the appropriateness of the developed model. As Chart 1 shows for the dependent variable, it can be observed that the residuals are normally distributed to a relative extent. According to this figure 15, if all points on the bisector are in the first quarter, then the data completely follow the distribution. According to Chart 1, the data almost follow the normal distribution.

Table. 5. Analysis of the distribution of residuals

Residuals Statistics ${ }^{a}$

\begin{tabular}{lccccc}
\hline & Minimum & Maximum & Mean & Std. Deviation & $\mathrm{N}$ \\
\hline Predicted Value & -1573.74 & 56362.82 & 5442.33 & 8887.990 & 332 \\
Residual & -16964.830 & 95041.664 & .000 & 6528.328 & 332 \\
Std. Residual & -2.575 & 14.426 & .000 & 1.000 & 332 \\
Stud. Residual & -2.686 & 15.335 & .000 & 1.039 & 332 \\
\hline
\end{tabular}

Dependent Variable: Extention

\section{CONCLUSIONS}

The Central Zagros as a bridge between the Iranian plateau and the lowlands of Mesopotamia ${ }^{42}$ has a special place in Middle Eastern archeological studies. In the Middle

\footnotetext{
${ }^{42}$ ABDI 1999, 33.
} 
Normal P-P Plot of Regression Standardized Residual

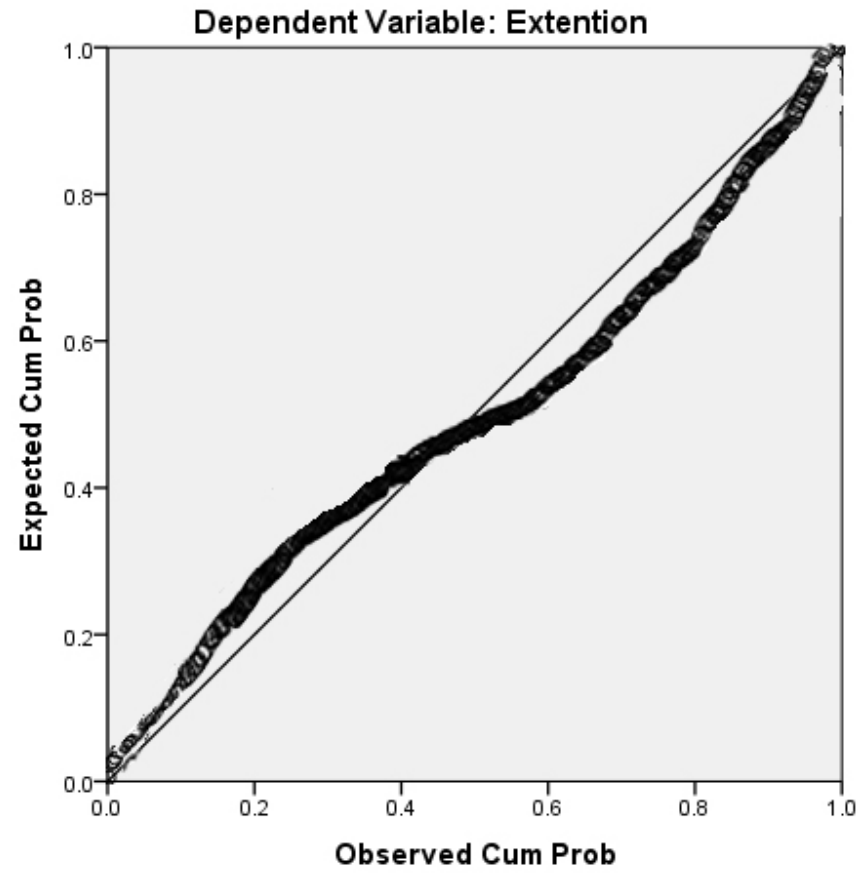

Fig. 15. Measurment of the normality of variables

East archeology, the Central Zagros as one of the richest and most important areas has been the focus of archaeologists in recent times. The Central Zagros is one of the key areas where native animals and plants such as goats, sheep, pigs and wheat were domesticated in the early Holocene ${ }^{43}$.

The Sar Firuzabad plain, which is located in the Merek River catchment, is a marginal plain along the Mahidasht plain in Kermanshah, which due to its climatic features, special and strategic geographical location, and rich sources of water and soil suitable for agriculture and location along the Great Khorasan Road $^{44}$ in the region has long been the focus of human groups. Accordingly, to determine the impact and relationship between environmental factors on the distribution of the Merek River catchment, an analysis was conducted between various ecological variables and the establishment and distribution of settlements based on statistical and environmental data. These studies emphasize the importance of the role of natural factors in the formation of cultural centers in the region. Statistical and environmental data indicate that the geographical features of the Merek River catchment, especially water resources, altitude, distance from communication routes and type of land use are the most important factors in the formation of settlement patterns in the region. Although other factors have played a role in this regard, the role of these factors has been more prominent than that of other factors.

In the distribution of settlements in the Merek River catchment, the distance from seasonal water sources such as seasonal rivers with a correlation coefficient of 0.225 , location in the region land use with a significant level of 0.01 , distance from communication paths with the correlation coefficient of 0.115 , and placement in relation to altitude levels with a correlation coefficient of -0.108 had

${ }_{43}$ ZESER 2009.

${ }^{44}$ HENRICKSON 1985, Fig 3. the greatest effect. It is noteworthy that the intensity of the impact of these factors in relation to Neolithic sites using multiple linear Regression analysis is equal to 0.906 . This number expresses a very high correlation between the set of environmental factors and the area of the sites. Furthermore, the results of the correlation and Regression coefficients indicate that the distribution of settlements in the Merek River catchment is regulated in relation to environmentalecological capabilities and constraints.

As mentioned, this plain is in fact a syncline that is drained by the Merek River, and there are also large and small alluvial fans on it. As we know, in many parts of the world, alluvial fans have provided a good opportunity for settlements and human settlements since prehistoric times owing to their suitable conditions ${ }^{45}$. In general, according to analyses and the relationship between ancient sites and environmental factors, it is shown that the settlements have been formed in two different contexts:

\section{1- High and foothill areas \\ 2- Fertile plains}

Statistics show that $43 \%$ are located in rolling hills and steppes and $57 \%$ are located in the plains. Settlements can be considered in higher and foothill areas. Studies demonstrate that the presence of water as an important and fundamental factor for development and population density is one of these important factors so that more than $64 \%$ of ancient centers are located less than 1000 meters from the river.

The influential factor of the environment has also provided a suitable platform for livestock and agricultural activities in how the archaeological sites and centers are created, or the reason for their establishment in the intermountainous plains of the region. The ancient sites of the region, being located along the communication paths and next to the permanent water sources and inside the sedimentary plain, demonstrate the importance of agriculture and sedentism and establishment of trade relations with other areas. Along with the sedimentary plains, there are also mountain steppe and forest steppe areas, which are the most suitable places to exploit these areas as suitable hunting areas or pastures for ranchers and nomads. By examining environmental factors, it is determined that the areas that are mainly located in the center of the plain and along or near the river and due to the slope of less than $10 \%$, owing to bing located in agricultural lands with an average height of 1500 meters, easy access to communication routes, richness of alluvial soils and forest areas around it, have the necessary potential for permanent settlements with agricultural livelihoods. Of these types of settlements, we can mention Tapeh Pachqa, but other types of sites that are located in rolling hills or at the foot of mountains, away from rivers and main communication routes, close to springs and rich pastures, and located on land high-sloping rocky outcrops are all seasonal sites with reliance on livestock and exploitation of natural resources in mountain ranges.

\footnotetext{
${ }^{45}$ MAGHSOUDI et alii 2012, 2.
} 


\section{ACKNOWLEDGEMENTS}

This article is the result of a postdoctoral research project of one of the authors (first), which has been done with the support of the Iranian National Science Foundation (INSF) with contract number 98005004; therefore, we are grateful for the support.

\section{REFERENCES}

ABDI 1999

Abdi, K., Archaeological research in the Islamabad Plain, Central Western Zagros Mountains, Preliminary results from the first season, summer 1998. DOI: 10.2307/4299992. Iran 37, 32-44.

ANABESTANI 2011

Anabestani, A. A., the Role of Natural Factors in Stability of Rural Settlements (Case Study: Sabzevar Country). Geography and Environmental Planning, 40(4), 89-104.

ANGERMEIER/KARR 1994

Angermeier, P. L./Karr, J. R. Biological integrity versus biological diversity as policy directives. Biosciences. Doi. org/10.2307/1312512. 44, 690-697.

BERTUZZO et alii 2007

Bertuzzo, E.,/Maritan, A.,/Gatto, M.,/Rodriguez, I.,/ Rinaldo, A., River networks and ecological corridors: Reactive transport on fractals, migration fronts, hydrochory. DOI: 10.1029/2006WR005533. Water Resources Research, 43, W04419.

BRAIDWOOD 1961

Braidwood, R., the Iranian Prehistoric project, 1959-1960. DOI: 10.1126/science.133.3469.2008. Iranica Antique 1, 3-7.

\section{BRAIDWOOD/HOW/REED}

Braidwood, R.,/Howe, B.,/Reed, c., The Iranian Prehistoric project. DOI: 10.1126/science.133.3469.2008. Science 133, 2008-2010.

BROOKS 1989

Brooks, I., The Physical Geography, geomorphology and late quaternary history of the mahidasht project area, qara su basin, central western Iran. Rom Mahidasht Project Report (Toronto: Royal Ontario Museum).

BROOKS/LEVINE/ROBIN 1982

Brooks, I.,/Levine, L.,/Robin, D., Alluvial sequence in central west Iran and implications for archaeological survey. Journal of Field Archaeology 9 (3), 285-299.

BUTZER 1980

Butzer, K. W., Context in archaeology: An alternative perspective. Journal of Field Archaeology 7, 417-422.

CAMPOS/FORT/MENSEZ 2006

Campos, D.,/Fort, J.,/Méndez, V., Transport on fractal river networks: Application to migration fronts. DOI: 10.1016/j. tpb.2005.09.001. Theoretical Population Biology 69(1), 88-93.

CEOLA/LAIO/MONTANARI 2015

Ceola, S.,/Laio, F.,/Montanari, A., Human-impacted waters: New perspectives from global high-resolution monitoring. DOI: 10.1002/2015WR017482. Water Resources Research 51(9), 7064-7079

\section{CLARCK 1977}

Clarke, D., Spatial analysis in archaeology, (new studies in archaeology) (Cambridge: Cambridge University Press).

FANG/JAWITZ 2019

Fang, Y.,/Jawitz, J. W., the evolution of human population distance to water in the USA from 1790 to
2010, DOI: 10.1038/s41467-019-08366-z. naturenature communications 10 (430), 1-8.

GOFF 1971

Goff, C., Luristan before the Iron Age. DOI: 10.2307/4300443. Iran 9, 131-152.

\section{HENRICKSON 1985}

Henrickson, E. F., early development of Pastoralism in the central Zagros Highlands (Luristan). DOI: 10.2143/ IA.20.0.2014076. Iranica Antiqua 12, 1-43.

\section{HENRICKSON 1989}

Henrickson, E. F., the Late Chalcolithic Period in the Central Zagros Highlands. Paléorient 15(1), 288 - 288.

HESHMATI et alii 2011

Heshmati, M.,/Arifin, A.,/Shamsouddin, A.,/Jusop, N.,/ Muhamad, M.,/Ghaituri, M., Factors affecting landslides occurrence in agro-ecological zones in the Merek catchment, Iran. Doi.org/10.1016/j.jaridenv.2011.06.011. Journal of Arid Environments 75, 1072-1082.

\section{HEYDARI/GHASIDIAN/CONARD 2007}

Heydari, S.,/Ghasidian, E.,/Conard, N. J., Karst landscape and Paleolithic settlement Zagros Mountains of Iran (Eberhard -Karls: UniversitatTubingen).

\section{HEYDARI 2016}

Heydari, M., Sarfirouzabad Plain in the Middle Chalcolithic Period: A Review of Dalma Settlements on the Eastern Edge of the Mahidasht, Central Zagros. DOI:10.22084/ nbsh.2016.1737. Pazhohesh-ha-ye Bastanshenasi Iran 6(11), 25-38 (In Persia).

\section{HOLE 1987}

Hole, F., the Archaeology of Western Iran: Settlement and Society from Prehistory to the Islamic Conquest (Washington D.C: Smithsonian Institute Press).

\section{KOUTSOYIANNIS/MAMASSIS 2018}

Koutsoyiannis, D./Mamassis, N., The water supply of Athens through the centuries, Proceedings of the 16th International Conference on the History of Water Management and Hydraulic in the Mediterranean Region Engineering (Greece, Athens) 31-42.

KUMMU et alii 2011

Kummu, M.,/De Moel. H.,/Ward, P. J.,/Varis, O., How close do we live to water? A global analysis of population distance to freshwater bodies. doi.org/10.1371/journal. pone.0020578. PLoS One (6) 6, 1-13.

MAGANZANI 2018, 87-106

Maganzani, L., Irrigation Communities in the Roman World through Epigraphic Sources and Justinian's Digest. In: Jonas Berking (ed.). Water Management in Ancient Civilizations (Berlin: Edition Topoi), 87-106.

\section{LEVINE 1974}

Levine, L. D., Archaeological investigations in the Mahidasht, Western Iran, Paléorient 2, 487-490.

\section{MAC DONALD 1979}

McDonald, M., an Examination of Mid- Holocene Settlement Patterns in the Central Zagros Region of Western Iran. Unpublished Ph.D. thesis, Department of Anthropology, University of Toronto.

\section{MAGHSOUDI 2008}

Maghsoudi, M. (2008). Assessment of Effective Factors on Evolution of Alluvial Fans Case Study: Jajroud Alluvial Fan. Physical Geography Research 65, 73-92

MAGHSOUDI et alii 2012

Maghsoudi, M.,/Fazeli Nashili, H.,/Azizi, G.,/Gilmour, 
G.,/Schmidt, A., Geoarchaeology of Alluvial Fans: A Case Study from Jajroud and Hajiarab Alluvial Fans in Iran. DOI: 10.22059/JPHGR.2012.30239. Physical Geography Research Quarterly 44(4), 1-22.

MOHAJER MILANI et alii 2010

Mohajer Milani, P.,/Eftekhari, K.,/Fatehi, S.,/Sepahvand, M.,/Turkelboom, F.,/De Pauw, E., Bruggeman, A., SemiDetailed Soil Surveys of Merek and Honam Watersheds, Karkheh River Basin, Iran (Aleppo, Syria: International Center for Agricultural Research in the Dry Areas Publisher).

NIKNAMI/NIKZAD 2012

Niknami, K. A.,/Nikzad, M., new evidence of the Neolithic period in West Central Zagros: the SarfirouzabadMahidasht Region, Iran. DOI: 10.4312/dp.39.33. Documenta Praehistorica XXXIX, 453-458.

NIKNAMI/ASKARPOUR 2013

Niknami, K. A.,/Askarpour, V., A GIS Modeling of Prehistoric Site Distribution in the Sarfirouzabad Plain of Kermanshah, Northwestern Iran. Doi.org/10.1260/20474970.2.3.343. International Journal of Heritage in the Digital Era 2, 343-359.

NIKNAMI/IRANDOUST/TAHMASEBI 2013

Niknami, K. A.,/Irandoust, H.,/Tahmasebi,A., Environmental and Cultural Factors Influencing Parthian Archaeological Site Distribution in the Sarfirouzabad Plain of Kermanshah, Northwest of Iran. DOI: 10.4236/ijg.2013.41008. International Journal of Geosciences, 4, 69-77.

NIKNAMI/ASKARPOUR 2015

Niknami, K. A.,/Askarpour, V. (2015). Pattern analysis of Chalcolithic settlements in the valley of Sarfirouzabad, Kermanshah, Iran. Archeologia e Calcolatori 26, 131-147.

NIKNAMI et alii 2016

Niknami, K. A.,/Mirghaderi, M. A.,/Alibaigi, S.,/ Bahramiyan, S., Middle and Late Bronze Age Sites in Sarfirouzabad Plain, Western Central Zagros, Iran. DOI: 10.2143/ANES.53.0.3154562. Ancient Near Eastern Studies 2(53), 81-112.

\section{NIKNAMI/MIRGHADERI 2019}

-Niknami, K. A.,/Mirghaderi, M. A., farmers, herders or tradesmen? Analyzing settlement patterns of the middle and late Bronze Age on the sarfirouzabad plain, Kermanshah, Western Iran. Doi.org/10.1111/j.16000390.2019.12205.x. Acta Archaeologica 90(1), 155-17.

\section{POTOSYAN 2017}

Potosyan, A. H., Geographical features and development regularities of rural areas and Settlements distribution in mountain countries. DOI: 10.1016/j.aasci.2017.02.012. Journal Annals of Agrarian Science 15(2), 1-5.

\section{SCHMIDT 1940}

Schmidt, E., Flights over Ancient Iran (Chicago:Universityof Chicago).

\section{SPRENT/SMEETON 2016}

Sprent, P.,/Smeeton, N. C., Applied Nonparametric Statistical Methods, 4 editions (London \& New York: Chapman and Hall).

\section{STEIN 1940}

Stein, A., Old Routes of Western Iran, narrative of an archaeological journey carried out and recorded (London: Macmillan and $\mathrm{Co}$ ).

\section{TURRERO et alii 2013}

Turrero, P.,/Dominguez-Cuesta, M. J.,/Monserrat, J. S.,/Garcia, V. E., The spatial distribution of Palaeolithic human settlements and its influence on palaeoecological studies: a case from Northern Iberia. doi.org/10.1016/j. jas.2013.06.003. Journal of Archaeological Science 40, 41274138.

\section{YAN/SU 2009}

Yan, X.,/Su, G., Linear Regression Analysis: Theory and Computing (New Jersey: World Scientific Publishing Co).

\section{VOGEL 1986}

Vogel, J., Subsistence settlement systems in the prehistory of south western Zambia. Doi.org/10.1007/BF00888306. Human Ecology 14, 397-414.

\section{VOS/MEEKES 1999}

Vos ,W.,/Meekes, H., Trend in European landscape development: Perspective for a sustainable future. Doi. org/10.1016/S0169-2046(99)00043-2. Landscape and Urban Planning 46, 3-14.

\section{ZEDER 2009}

Zeder, M., The Neolithic macro-(r)evolution: Macroevolutionary theory and the study of culture change. DOI: 10.1007/s10814-008-9025-3. Journal of Archaeological Research 17, 1-63.

\section{ZHANG et alii 2014}

Zhang, R.,/Jiang, D.,/Zhang, L.,/Cui, Y.,/Li, M.,/Xiao, L., Distribution of nutrients, heavy metals, and PAHs affected by sediment dredging in the Wujin'gang River basin flowing into Meiliang Bay of Lake Taihu. doi: 10.1007/s11356-0132123-x. Environmental Science and Pollution Research 21, 2141-2153.

\section{ZOMORODIAN 2004}

Zomorodian, M. J., Application of Natural Geography in Urban and Rural Planning (Tehran: Payame Noor Publishing House). 